\title{
KOINTEGRASI DAN KAUSALITAS INDEKS HARGA SAHAM GABUNGAN DAN DOW JONES INDUSTRIAL INDEX
}

\author{
Paulus Sulluk Kananlua \\ Program Studi Manajemen, Fakultas Ekonomi dan Bisnis Universitas Bengkulu \\ Paulus_Kananlua@yahoo.com
}

\begin{abstract}
ABSTRAK
Paulus Sulluk Kananlua; Penelitian ini untuk menganalisis dampak dari krisis keuangan global yang terjadi di Amerika dan surrogated oleh Indeks Dow Jones Industrial (DJI) terhadap Bursa Efek Indonesia, diwakili oleh indeks komposit (IHSG). Penelitian ini dilakukan dengan menggunakan data time series mulai dari Januari 2007 sampai Juli 2014. Data yang digunakan terdiri dari observasi 60 bulan. Dalam rangka untuk memeriksa data time series, Vector Autoregressive Model (VAR) yang digunakan. Kami menjalankan alat statistik untuk memperkirakan respon yang disebabkan oleh guncangan dari variabel penelitian. Sebelum mengestimasi model Vector Autoregression (VAR), data yang digunakan harus mengikuti tes unit root, uji kointegrasi, uji kausalitas granger, dan kemudian runned dengan menggunakan model VAR. Hasil kami menunjukkan bahwa data tidak stasioner pada level, tetapi stasioner pada perbedaan pertama. Output estimasi ditafsirkan dihasilkan dari fungsi respon impuls dan variance decomposition menunjukkan bahwa respon DJI ini jauh lebih besar disebabkan oleh guncangan dari DJI sendiri dengan jumlah rata-rata berdiri di atas 99,36\%. Selanjutnya, proporsi IHSG rata-rata adalah $0,64 \%$. Sementara itu respon dari IHSG yang dipicu oleh DJI adalah 53,10\% rata-rata. nilai tetap sebagai $46,90 \%$ disebabkan oleh shock dari IHSG.
\end{abstract}

\begin{abstract}
Paulus Sulluk Kananlua; This research is obviously intended to analyze the impact of global financial crisis which happened in America and surrogated by the Dow Jones Industrial Index (DJI) towards the Indonesian Stock Exchange, represented by the composite index (IHSG). The study is conducted by using time series data ranging from January 2007 to July 2014. Data used consists of 60 months observation. In order to examine the time series data, Vector Autoregressive Model (VAR) is employed. We run the statistical tool to estimate the respon caused by the shock of research variable. Before estimating the model of Vector Autoregression (VAR), the data used must following the unit root test, cointegration test, granger causality test, and then runned by using VAR model. Our result reveals that the data is not stationer at level, but stationer at first difference. The interpreted estimation output resulting from impulse response function and variance decomposition show that DJI's respons is much bigger caused by the shock from DJI itself with average number stand on $99.36 \%$. Further, the proportion of IHSG on average is $0.64 \%$. Meanwhile the respon of IHSG sparked by the DJI is $53.10 \%$ on average. The remained value as $46.90 \%$ is caused by the shock from IHSG.
\end{abstract}

\section{Key Words: DJI, IHSG, VAR, Unit Root Test, Cointegration Test, Granger Test, Impulse Response, Variance Decomposition}

\section{PENDAHULUAN}

Krisis ekonomi yang melanda perekonomian global pada tahun 2007 menyebabkan sebagian besar pertumbuhan ekonomi negara-negara maju maupun negara berkembang menurun secara drastis. Dampak krisis tersebut menjadi salah satu faktor yang notabene mempengaruhi perekonomian dunia secara langsung. Merambahnya dampak krisis global ini ditandai dengan semakin banyaknya penurunan nilai indeks harga saham disetiap pasar modal. Penurunan ini dapat terjadi karena sebagian besar aktivitas perekonomian antar negara saling terintegrasi satu sama lain.

Krisis keuangan Global yang berawal di Amerika kian merambat ke Eropa hingga ke Asia. Hal ini berdampak tidak hanya pada aktivitas perdagangan pasar saham di Eropa dan Amerika, tetapi juga pada pasar saham di benua lainnya yang terintegrasi langsung dengan pasar modal Amerika (Kaniawati, 2009). Indonesia yang terletak di Benua Asia juga turut merasakan dampak yang dihasilkan oleh krisis perekonomian tersebut. Tetapi dampak yang dirasakan tidak separah yang dialami oleh negara-negara maju dan berkembang lainnya, di mana Pasar modal Indonesia masih mampu bertahan hingga menjadi pasar modal yang memiliki nilai penutupan nomor 2 terbaik di Asia Pasifik setelah Philipina. Selain itu, 
pasar modal Indonesia juga menjadi pasar modal terbaik nomor 8 di Dunia pada akhir tahun 2011 (Media Indonesia, 30 Desember 2011).

Berbanding terbalik dengan pasar modal Amerika, di mana terjadi koreksi cukup tajam yang ditunjukkan oleh Dow Jones Index (DJI). Pada tahun 2007, nilai pasar DJI merosot tajam dari 13.264 ke titik terendahnya pada level 7.608 di bulan maret tahun 2009. Hal ini menandakan bahwa krisis yang terjadi di Amerika sangat berdampak pada aktivitas perekonomiannya. Namun demikian, Amerika tidak hanya terintegrasi dengan pasar modal di Eropa saja, tetapi juga terintegrasi dengan pasar modal di negara berkembang lainnya seperti Indonesia.

Dampak buruk dari krisis perekonomian Global yang merambah Amerika, Indonesia, dan negaranegara lainnya dapat dilihat dari kecenderungan merosotnya investasi yang terjadi di pasar modal Indonesia. Husnan (1994) mengungkapkan bahwa ada beberapa kecenderungan yang dapat diamati, yaitu kegiatan utama di pasar sekunder masih didominasi oleh perdagangan saham. Kedua, bursa masih menjadi alternatif pendanaan bagi perusahaan besar. Ketiga, peran pemodal asing masih sangat besar. Selain itu, dua faktor yang menyebabkan pasar modal membuka diri bagi pemodal asing adalah dana yang dimiliki dan pengalaman analisis yang dimiliki oleh investor-investor tersebut.

Begitu terbukanya pasar modal Indonesia terhadap para pemodal asing berakibat pada besarnya pengaruh bursa-bursa di luar negeri terhadap Bursa Efek Indonesia. Roll, (1994) dalam Husnan (1994) menunjukkan bahwa terjadi kecenderungan pasar modal Indonesia makin terintegrasikan dengan pasar modal lain di Dunia. Hal ini menyebabkan apabila terjadi shock atau gangguan keuangan dipasar modal yang terintegrasi dengan pasar modal Indonesia, mengakibatkan pasar modal Indonesia juga mengalami hal serupa sebagai dampak dari terbukanya pasar modal Indonesia terhadap bursa-bursa saham di negara-negara lain. Hal inilah yang terjadi di antara pasar modal Amerika (AMEX) dan pasar modal Indonesia (BEI), di mana terdapat integrasi yang menyebabkan pergerakan nilai indeks di kedua Negara ini cenderung menunjukkan tren pergerakan yang hampir sama.

\section{Gambar 1. Perkembangan Pergerakan Nilai Indeks DJI dan IHSG Selama Periode Waktu 1 Januari 2007 - Juli 2014}

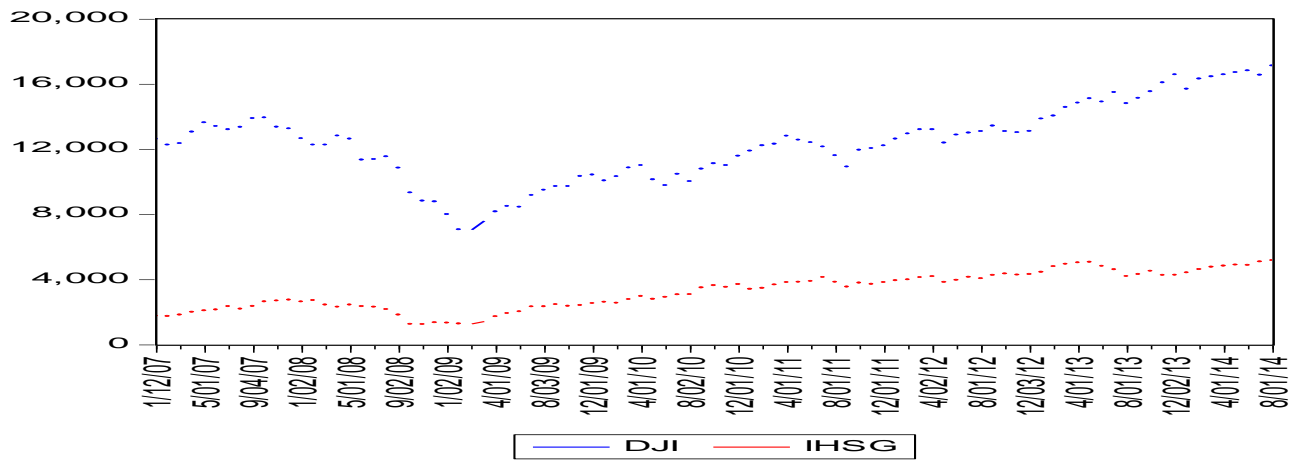

Gambar 1.1 menunjukkan pergerakan Bursa Efek Amerika (AMEX) yang diproksi oleh Dow Jones Index (DJI) mengalami penurunan sebagai akibat krisis keuangan Global yang dipicu oleh kegagalan Amerika dalam mengelola kredit perumahannya (Subprime mortagages). Krisis keuangan yang terjadi di Amerika turut berdampak langsung pada kinerja perdagangan di Bursa Efek Indonesia (IDX). Selain itu, menurunnya kinerja Bursa Efek Amerika juga juga berbanding lurus dengan menurunnya kinerja Bursa Efek Indonesia di periode pengamatan yang sama. Hal ini dibuktikan dengan turut turunnya aktivitas perdagangan di BEI yang diproksi oleh Indeks Harga Saham Gabungan (IHSG). Selanjutnya pada saat DJI mengalami penurunan nilai indeks dipertengahan tahun 2008, hal yang sama juga terjadi pada IHSG, di mana IHSG merespon shock yang terjadi pada DJI sebagai sebuah akibat dari terintegrasinya pasar modal Indonesia dengan pasar modal Amerika.

Telah banyak penelitian yang meneliti pengaruh pergerakan nilai bursa asing terhadap bursa efek Indonesia, tetapi masih sedikit penelitian yang meneliti dampak runtutan krisis ekonomi yang diproksi oleh sebuah indeks bursa terhadap indeks bursa negara lain yang saling terintegrasi. Sebelumnya Husnan (1994) meneliti bahwa semakin terintegrasi dan terbukanya pasar modal Indonesia terhadap pasar modal asing, menyebabkan semakin rentannya pasar modal Indonesia terhadap kemungkinan risiko yang terjadi pada pasar modal yang terintegrasikan tersebut. Selain itu Husnan (1994) juga menyatakan bahwa semakin besar proporsi investasi asing di Bursa Efek Indonesia, semakin besar peluang asing untuk mendominasi jumlah saham yang diperdagangkan. Lebih jauh, Mauliano (2009) meneliti korelasi antara berbagai macam bursa yang saling terintegrasi seperti DJI, NYSE, FTSE, STI, N225, HSI, KOSPI, KS11 dan KLSE. Hasil penelitianya menunjukkan bahwa selama periode 
pengamatan pada tahun 2004 sampai 2009, ditemukan korelasi yang kuat antara indeks bursa yang saling terintegrasi tersebut. Hal yang lebih mengejutkan menunjukkan bahwa indeks bursa asing ternyata lebih mendominasi Indeks Harga Saham Gabungan di Indonesia. Besarnya dominasi asing terhadap Bursa Efek Indonesia tentu saja berdampak pada pergerakan indeks dalam negeri, sehingga munculnya krisis ekonomi menjadi topik menarik untuk dikaji secara komprehensif. Demikian, fokus utama penelitian ini adalah untuk menjawab, (1) apakah (shock) krisis keuangan global yang menerpa Bursa Efek Amerika (AMEX) yang diproksi dengan Dow Jones Index (DJI) berpengaruh terhadap Bursa Efek Indonesia (IDX) yang diproksi dengan Indeks Harga Saham Gabungan (IHSG)? (2) apakah hubungan kausalitas antara Bursa Efek Amerika (AMEX) yang diproksi oleh Dow Jones Index (DJI) dan Bursa Efek Indonesia (IDX) yang diproksi oleh Indeks Harga Saham Gabungan (IHSG) bersifat dua arah?

\section{LANDASAN TEORI \\ Integrasi Antara Pasar Modal}

Pandangan ekonomi mainstream menyebutkan bahwa arus dana yang keluar masuk dari suatu negara yang berinteraksi dengan negara lainnya, akan membawa manfaat terhadap negara tersebut. Manfaat pertama yang dihasilkan dapat berupa portofolio investasi yang dapat menyediakan non-debt creating investasi bagi negara berkembang yang sedang mengalami kelangkaan modal. Dengan adanya arus modal asing, dapat menambah tabungan domestik untuk meningkatkan investasi. Di samping menyediakan mata uang asing kepada Negara yang sedang berkembang, arus modal asing juga mengurangi tekanan gap kurs mata uang bagi negara-negara tersebut yang selanjutnya dapat membuat aktivitas impor lebih mudah.Kedua, kenaikan arus modal asing ke pasar modal suatu Negara dapat meningkatkan alokasi modal menjadi lebih efisien bagi negara tersebut. Arus modal seperti penanaman modal langsung dapat merangsang negara-negara lain yang kelebihan modal agar mengalirkan dananya kepada negara yang kekurangan modal, dimana return yang ditawarkan negara tersebut pada umumnya lebih menarik (BAPEPAM, 2008).

Arus modal asing yang terjadi sebagai akibat integrasi pasar modal juga dapat mendorong stimulasi perkembangan pasar modal domestik suatu negara. Perkembangan pasar modal domestik tersebut terjadi melalui kompetisi di antara pemodal institusi. Kompetisi ini menciptakan teknologi keuangan yang semakin canggih dan memerlukan investasi dalam bidang informasi serta aktivitas jasa keuangan. Kompetisi ini pada akhirnya membawa efisiensi alokasi capital dan risk sharing. Peningkatan efisiensi tersebut terjadi karena adanya internasionalisasi yang membuat pasar menjadi lebih likuid, selanjutnya cost of foreign capital semakin murah karena portfolio asing dapat didiversifikasi diantara negara-negara yang saling terintegrasi.

Pasar modal yang sudah maju menerima dampak arus modal asing dari sisi demand. Di pasar modal tersebut akan tersedia sekumpulan aset dengan berbagai risiko, return dan likuiditas. Hal ini meningkatkan pilihan aset dan mendorong pasar modal menjadi lebih vibrant, karena menyediakan likuiditas yang tinggi bagi penabung atau pemodal untuk selanjutnya meningkatkan tabungan.

\section{PENELITIAN SEBELUMNYA}

Husnan (1994) meneliti bahwa pasar modal yang terbuka terhadap pasar modal asing cenderung rentan terhadap fluktuasi pasar partnernya. Hal ini mengakibatkan adanya hubungan interdependesi antara dua pasar yang saling terintegrasi tersebut. Dependensi ini muncul sebagai akibat keterbukaan pasar yang memungkinkan salah satu pihak untuk meakukan dominasi terhadap pasar modal partnernya. Dengan dasar yang sama, Mauliano (2009) meneliti keterkaitan antara beberapa bursa asing terhadap kinerja Bursa Efek Indonesia. Hasil penelitiannya mengungkapkan bahwa sebagian besar Indeks Bursa asing yang masuk ke dalam penelitiannya mendominasi Indeks Harga Saham Gabungan di Bursa Efek Indonesia.

Lebih lanjut Parthapratim (2006) menguji pengaruh investasi portofolio asing pada ekonomi dan industri di India. Investasi portofolio asing pada dasarnya berinteraksi dengan ekonomi rill melalui pasar saham. Temuan dari penelitian ini menunjukkan bahwa manfaat yang dirasakan oleh investasi portofolio asing belum tercapai di India. Investasi portofolio secara keseluruhan berkonsentrasi pada pasar sekunder, namun mekanisme transmisi oleh aktivitas pasar sekunder di pasar saham untuk mendorong ekonomi riil belum terlihat di India.

Penelitian terbaru mengenai kointegrasi dua pasar modal yang saling berhubungan pernah dikaji oleh Nurazi, Zulkarnain dan Kananlua, (2013). Hasil penelitiannya mengungkapkan bahwa terdapat ketergantungan yang tinggi dari pasar modal Indonesia terhadap pasar modal Cina yang diproksi dengan Shanghai Composite Index (SHCOMP). Keterbukaan yang tinggi dan kerjasama di bidang ekonomi antara kedua negara ini membuat kinerja kedua Negara saling mempengaruhi satu sama lain. Namun demikian, berdasarkan hasil yang diperoleh, pengaruh yang duji dengan menggunakan uji Granger test 
menunjukkan dominasi Bursa Efek Cina lebih besar terhadap Bursa Efek Indonesia. Hal ini semakin memperjelas bahwa pada saat Bursa Efek Cina mengalami shock berupa krisis atau penurunan kinerja ekonomi, turut berdampak pada terkoreksinya nilai IHSG.

\section{METODOLOGI}

Penelitian ini merupakan jenis penelitian deskriptif kuantitatif. Data dan informasi yang diperoleh didentifikasi dan dideskripsikan dengan menggunakan bantuan alat analisis statistik. Lebih lanjut, penelitian ini menekankan pada penggunaan data sekunder, yaitu dengan melakukan identifikasi dan menguraikan fenomena yang terjadi berdasarkan informasi yang diperoleh dari data penelitian.

\section{Sampel}

Penelitian ini menguji hubungan sebab akibat, dan kointegrasi antara Bursa Efek Amerika (AMEX) dan Bursa Efek Indonesia (BEI). Untuk lebih memperjelas obyek penelitian, maka populasi yang digunakan dalam penelitian ini adalah Bursa Efek Amerika dan Bursa Efek Indonesia. Sedangkan sampel yang digunakan dalam penelitian ini terdiri dua harga atau nilai indeks saham gabungan di kedua Negara Amerika dan Indonesia, yaitu data perdagangan Dow Jones Index (DJI) dan indeks harga saham gabungan (IHSG) yang diambil dalam bentuk times series bulanan selama kurun waktu dari 1 Januari 2007 sampai dengan 31 Juli 2014.

\section{Definisi Operasional Variabel}

Penelitian ini menggunakan data sekunder berupa data time series, yaitu data yang diperoleh secara tidak langsung dari pihak lain atau media perantara berupa bukti, catatan, atau laporan historis yang telah tersusun dalam arsip yang telah dipublikasikan atau tidak dipublikasikan (Cooper \& Schindler 2011). Data yang digunakan dalam penelitian ini terdiri dari 91 data observasi yang dihimpun secara bulanan, dari bulan Januari 2007 sampai bulan Desember 2014. Sebagai langkah untuk memperjelaskan proses pengukuran terhadap variabel yang digunakan, maka dilakukan operasionalisasi variabel sebagai berikut:

1. Hubungan kointegrasi dan hubungan kausalitas: adalah hubungan sebab akibat yang diukur dengan menggunakan derajat waktu jangka panjang. Dalam penelitian ini, rentang waktu yang digunakan adalah selama 91 bulan.

2. Hubungan kausalitas dinamis: merupakan hubungan antara dua bursa efek yaitu Bursa Efek Amerika dan Bursa Efek Indonesia yang dimodelkan dengan pemodelan Vector autoregressive.

3. Dow Jones Index (DJI) merupakan indeks saham gabungan di Bursa Efek Amerika.

4. Indeks Harga Saham Gabungan (IHSG) merupakan indeks saham gabungan di Bursa Efek Indonesia.

\section{Metode Analisis}

Dalam hubungan antar variabel ekonomi sering ditemui adanya kelambanan, karena menyangkut perilaku manusia (Widarjono, 2009). Hal ini tentunya juga dapat terjadi dalam hubungan antara variabel makro terhadap fluktuasi harga saham. Jika ada perubahan variabel makro, belum tentu dengan serta merta akan mengubah return saham (Lestari, 2005). Kadang-kadang untuk melihat pengaruhnya diperlukan waktu penyesuaian atau kelambanan. Secara teori timbulnya kelambanan semacam ini disebabkan oleh tiga faktor, yaitu faktor psikologis, faktor kelembagaan, dan faktor teknologi (Gujarati, 1998). Adanya kelambanan ini akan mengakibatkan regresi linier saja sering tidak bias menjawab apa yang dikehendaki teori.

Sebagai langkah untuk mengatasi adanya faktor kelambanan, maka model yang digunakan dalam penelitian ini adalah model Vector Auto Regressive (VAR). Sedangkan untuk mengetahui dampak respon masing-masing variabel sebagai akibat suatu goncangan (shock), digunakan analisis impulse response (impulse response analysis) dan dekomposisi varian (variance decomposition). Selanjutnya, basis data yang digunakan dalam penelitian ini adalah data nilai Dow Jones Index (DJI) dan Indeks Harga Saham Gabungan (IHSG) yang diperoleh secara bulanan. Observasi terhadap data tersebut dimulai dari bulan Januari 2007 sampai bulan Juli 2014.

\section{Uji Akar-Akar Unit (Unit Root Test)}

Estimasi model ekonometrik time series akan menghasilkan kesimpulan yang tidak berarti ketika data yang digunakan mengandung akar unit (tidak stasioner). Keadaan data yang tidak stasioner ini dapat menghasilkan kondisi Regresi lancung (spurious regression) pada hasil estimasi regresi. Hal ini ditandai dengan tingginya koefisien determinasi $\mathrm{R}^{2}$ dan nilai t stasistik yang tidak signifikan. Adanya hasil regresi lancung (spurious regression) akan mengarahkan pada hasil penafsiran yang menyesatkan (Insukindro, 
1998). Lebih jauh, data time series dikatakan stasioner jika rata-rata varian dan kovarian pada setiap lag adalah tetap atau sama pada setiap waktu (Widarjono, 2009).

Uji stasioneritas dapat dilakukan dengan beberapa metode. Salah satu metode yang dapat digunakan adalah dengan menggunakan correlogram dengan melihat koefisien ACF dan PACF (Widarjono, 2009). Selain itu Gujarati (1995) juga menyatakan bahwa selain uji ACF dan PACF, uji DF (Dickey Fuler) dan ADF (Augmented Dickey fuller) dapat dijadikan prosedur standar untuk menguji hipotesis nol (H0) adanya akar unit (seri tidak stasioner) terhadap hipotesis alternatif (H1) sebuah seri stasioner. Jika $Y_{t}$ adalah seri dengan panjang lag p, maka:

Di mana:

$$
\Delta Y_{t}=\alpha_{0}+\gamma Y_{t-1}+\beta_{i} \sum_{i=1}^{p} \Delta Y_{t-i+1} \varepsilon_{t}
$$

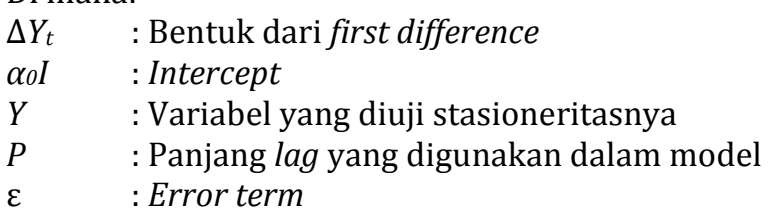

\section{Penentuan Lag Optimal}

Salah satu permasalahan yang muncul pada saat melakukan uji stasioneritas dalam analisis Vector Autoregressive (VAR) adalah penentuan lag yang optimal. Jika lag yang digunakan dalam uji stasioneritas terlalu sedikit, maka residual dari regresi tidak akan menampilkan proses white noise sehingga model tidak dapat mengestimasi actual error secara tepat. Hal yang terjadi sebagai akibat terlalu sedikitnya lag dalam mengestimasi adalah $\gamma$ dan standar error tidak diestimasi dengan baik. Namun jika memasukan terlalu banyak lag maka dapat mengurangi kemampuan untuk menolak $\mathrm{H}_{0}$. Hal ini terjadi karena dengan bertambahnya parameter yang berlebihan akan mengurangi degree of freedom (Harris, 1995).

Untuk menentukan lag optimal, maka dalam penelitian ini digunakan beberapa kriteria informasi yang terdiri dari Akaike Information Criterion (AIC), Schwart information Criterion (SIC) dan HannanQuinn (HQ) yang paling kecil di antara berbagai lag yang diajukan. Selanjutnya, penelitian ini menggunakan 91 bulan observasi dengan periode pengamatan dari Januari 2007 sampai Juli 2014. Dengan begitu, jumlah lag yang akan diujikan adalah sebanyak 6 Lag.

\section{Uji Kausalitas Granger}

Metode yang digunakan untuk menganalisis hubungan kausalitas antar variabel yang diamati adalah dengan melakukan uji kausalitas Granger. Uji kausalitas Granger ditujukan untuk melihat arah hubungan antar variabel DJI dan IHSG. Widarjono (2009) menyatakan bahwa adanya kointegrasi antara dua variabel mengindikasikan bahwa ada hubungan atau keseimbangan jangka panjang antara kedua variabel tersebut. Dalam jangka pendek, bisa saja ada ketidakseimbangan (disequilibrium). Hal ini berarti apa yang diinginkan pelaku ekonomi (desired) belum tentu sama dengan apa yang terjadi sebenarnya. Dengan adanya perbedaan maka diperlukan penyesuaian (adjustment). Model yang memasukan penyesuaian untuk melakukan koreksi bagi ketidakseimbangan disebut sebagai model koreksi kesalahan (error correction model).

Apabila kedua variabel yang diujikan pada penelitian ini tidak stasioner pada tingkat level, maka keduanya diindikasikan mengandung kointegrasi. Hal ini berarti ada hubungan atau kesimbangan jangka panjang antara kedua variabel tersebut. Model ECM Engle-Granger dalam penelitian ini ditulis sebagai berikut:

Di mana:

$$
\Delta Y=\beta_{0}+\beta_{1} \Delta X_{t}+\beta_{2} \mathrm{EC}_{t}+\varepsilon_{t}
$$

$\begin{array}{ll}\Delta Y & : \text { IHSG } \\ \mathrm{X} & : \mathrm{DJI} \\ \mathrm{EC} C_{t} & :\left(\mathrm{Y}_{\mathrm{t}-1}-\beta_{0}-\beta_{1} \mathrm{X}_{\mathrm{t}-1}\right)\end{array}$

\section{Uji Kointegrasi}

Widarjono (2009) dalam bukunya menjelaskan bahwa metode Johansen menjadi salah satu pendekatan yang dapat digunakan dalam uji kointegrasi. Uji kointegrasi dengan metode Johansen dapat dianalisis melalui model Autoregressive dengan ordo P yang ditunjukkan oleh persamaan berikut;

Di mana:

$$
y_{t}=A_{1} y_{t-1}+\ldots \ldots \ldots+A_{p} y_{t-p I}+B \pi_{t}+\varepsilon t
$$

yt : Vektor-k pada variabel-variabel yang tidak stasioner 
$\pi_{t} \quad$ : Vektor-d pada variabel deterministik

$\varepsilon_{t} \quad$ : Vektor inovasi

Selanjutnya persamaan tersebut dapat ditulis ulang menjadi:

Di mana:

$$
\Delta Y_{t}=\Pi y_{t-1}+\beta_{i} \sum_{i=1}^{p-1} \Gamma_{\mathrm{i}} \Delta Y_{t-i}+\mathrm{B} \pi_{t}+\varepsilon_{t}
$$

$$
\Pi=\sum_{i=1}^{p} A_{i}-\mathrm{I}, \Gamma_{i}-\sum_{j=i+1}^{p} A_{j}
$$

Representasi teori Granger menyebutkan bahwa koefisien matriks П memiliki $\tau<\mathrm{k}$ reduce rank yang mempunyai $\mathrm{kx} \tau$ matriks $\alpha$ dan $\beta$ dengan rank, seperti $\Pi=\alpha \beta$ dan $\beta^{\prime} y_{t}$ yang merupakan I (0). T merupakan bilangan kointegrasi (rank), sedangkan tiap kolom $\beta$ menunjukan vector kointegrasi. $\alpha$ lebih dikenal dengan parameter penyesuaian pada VECM. Selanjutnya metode Johansen digunakan untuk mengestimasi matriks $\Pi$ dari unrestricted VAR dan untuk melakukan pengujian apakah hasil reduced rank $\Pi$ dapat diterima atau tidak.

Selanjutnya dalam pengujian reduce rank tersebut, Johansen menggunakan dua tes statistik yang berbeda yaitu trace test ( $\left.\lambda_{\text {trace }}\right)$ dan maximum eigenvalue test $\left(\lambda_{\max }\right)$. Trace test menguji $\mathrm{H} 0$ pada persamaan kointegrasi $\tau$ sebagai kointegrasi alternatif dari persamaan kointegrasi-k dimana $\mathrm{k}$ merupakan bilangan variabel endogen untuk $\tau=0,1, \ldots . ., \mathrm{k}-1$.

\section{Estimasi VAR}

Metode Vector Auutoregression adalah Model persamaan regresi yang mengunakan data time series. Model ini pertama kali dikembangkan oleh Christopher Sims pada tahun 1980. Kerangka analisis yang praktis dalam model ini akan memberikan informasi yang sistematis dan mampu menaksir dengan baik informasi dalam persamaan yang dibentuk dari data time series. Selain itu, perangkat estimasi dalam model VAR mudah digunakan dan diinterpretasikan. Perangkat estimasi yang digunakan dalam model VAR ini adalah fungsi impulse dan variance decomposition. Persoalan yang muncul dalam di dalam data time series adalah berkaitan dengan stasioneritas data dan kointegrasi antar variabel di dalamnya.

Model VAR menganggap bahwa semua variabel ekonomi adalah saling tergantung satu sama lain. Lebih jauh Gujarati (1995) mengungkapkan beberapa keuntungan dengan menggunakan VAR, di antaranya adalah:

1. VAR mampu melihat lebih banyak variabel dalam menganalisis fenomena ekonomi jangka pendek dan jangka panjang.

2. VAR mampu mengkaji konsistensi model empirik dengan teori ekonometrika.

3. VAR mampu mencari pemecahan terhadap persoalan variabel runtun waktu yang tidak stasioner dan regresi lancung atau korelasi lancung dalam analisis ekonometrika.

Karena dalam penelitian ini variabel yang diamati terdiri dari dua variabel, maka spesifikasi model penelitiannya dinamakan bivariate vector autoregression, di mana hubungan interdependensi antara DJI dan IHSG dispesifikasikan dalam sistem persamaan yang terdiri atas dua persamaan sebagai berikut:

Di mana:

$$
\begin{gathered}
I H S G_{t}=\alpha_{1}+\sum_{i=1}^{2} \beta_{i} D J I_{t-1}+\sum_{i=1}^{2} \gamma_{i} I H S G_{t-i}+\varepsilon_{1 t} \\
D J I_{t}=\alpha_{2}+\sum_{i=1}^{2} \theta_{i} D J I_{t-1}+\sum_{i=1}^{2} \lambda_{i} I H S G_{t-i}+\varepsilon_{2 t}
\end{gathered}
$$

DJI

IHSG

$$
\begin{aligned}
& \text { : Down Jones Index } \\
& \text { : Indeks Harga Saham Gabungan }
\end{aligned}
$$

$\varepsilon_{1 \mathrm{t}}$ dan $\varepsilon_{2 \mathrm{t}}$ adalah proses white noise (independen terhadap perilaku historis DJI dan IHSG. Pada persamaan (1), pola pergerakan harga saham IHSG dipengaruhi oleh variabel pergerakan harga IHSG sendiri pada periode sebelumnya dan oleh pola pergerakan DJJI sebelumnya. Begitu juga sebaliknya. Estimasi terhadap model VAR ini dapat dilakukan dengan metode ordinary least square (OLS) dengan asumsi bahwa white noise $\varepsilon_{1 \mathrm{t}}$ dan $\varepsilon_{2}$ independen terhadap nilai historis variabel yang diamati, maka parameter estimasi model yang diperoleh dengan metode estimasi OLS konsisten.

\section{Fungsi Impulse Response}

Fungsi impulse response pada dasarnya menelusuri pengaruh goncangan standar deviasi terhadap perubahan-perubahan nilai variabel endogen periode sekarang dan periode ke depan. Goncangan terhadap variabel $i$ secara langsung akan berpengaruh pada variabel tersebut, dan menyebar dampaknya kepada seluruh variabel endogen melalui struktur dinamis VAR (Kurnia, 2005). 
Lebih lanjut Widarjono (2009) menyatakan bahwa koefisien yang secara individual berada di dalam model VAR sulit untuk diinterpretasikan, maka itu para ahli menggunakan analisis impulse response. Impulse response ini merupakan salah satu analisis penting di dalam model VAR. Widarjono (2009) menyatakan analisis impulse response ini digunakan untuk melacak respon dari variabel endogen di dalam sistem VAR karena adanya gonjangan (shocks) atau perubahan di dalam variabel gangguan $(\varepsilon)$. Impulse response dalam penelitian ini difokuskan untuk mengetahui respon IHSG dan DJI apabila terdapat shock $\mathrm{u}_{\mathrm{IHSG}}$ dan $\mathrm{u}_{\mathrm{DJI}}$.

Dalam kasus bivariate VAR antara DJI dan IHSG, maka persamaan yang diamati dalam penelitian ini adalah sebagai berikut:

$$
\begin{gathered}
I H S G_{t}=\alpha_{11} I H S G_{t-1}+\alpha_{12} D_{J I} I_{t-1}+\varepsilon_{1 t} \\
D J I_{t}=\alpha_{21} I H S G_{t-1}+\alpha_{22} D J I_{t-1}+\varepsilon_{2 t}
\end{gathered}
$$

Perubahan pada $\varepsilon_{1 t}$ akan segera berpengaruh terhadap nilai IHSG sekarang, begitu juga hal tersebut akan berpengaruh terhadap nilai IHSG dan DJI periode selanjutnya. Hal ini disebabkan baik karena lag IHSG dan lag DJI ada dalam dua persamaan tersebut. Jika dua variabel inovasi $\varepsilon_{1 \mathrm{t}}$ dan $\varepsilon_{2 \mathrm{t}}$ dalam contoh persamaan tersebut tidak berkorelasi, interprestasi fungsi impulse response bersifat langsung, dimana $\varepsilon_{1 t}$ merupakan variabel inovasi untuk IHSG dan $\varepsilon_{2 t}$ untuk variabel DJI.

Dalam kenyataannya, variabel innovasi $\varepsilon_{11}$ dan $\varepsilon_{2 t}$ biasanya saling berkorelasi sehingga keduanya memiliki komponen bersama dalam dampaknya terhadap variabel endogen, keduanya tidak bisa dipisahkan dampaknya terhadap variabel secara terpisah. Dengan saling berkorelasinya variabel, maka tidak bisa diketahui respon suatu variabel yang berasal dari variabel inovasi secara terpisah. Oleh karena itu, Variance Decomposition diperlukan untuk memisahkan dampak masing-masing variabel inovasi tersebut secara individual terhadap respon yang diterima suatu variabel (Kurnia, 2005).

\section{Variance Decomposition}

Selain impulse response, model VAR juga menyediakan analisis forecast error decomposition of variance atau seringkali disebut dengan variance decomposition. Widarjono (2009) menyatakan bahwa Analisis ini menggambarkan relatif pentingnya setiap variabel di dalam sistem VAR karena adanya shocks. Variance decomposition berguna untuk memprediksi kontribusi persentase varian setiap variabel karena adanya perubahan variabel tetentu di dalam sistem VAR. Dalam penelitian ini, varian decomposition ditujukan untuk mengetahui proporsi varians $\sigma_{\mathrm{DJI}}$ dan $\sigma_{\mathrm{IHSG}}$ karena shock $\mathrm{uDJI}_{\mathrm{JI}}$ dan uIHSG.

\section{HASIL DAN PEMBAHASAN}

\section{Volatilitas DJI dan IHSG Selama Kurun Waktu 2007-2014}

Dow Jones Index (DJI) dan Indeks Harga Saham Gabungan (IHSG) merupakan dua indeks harga saham besar yang menjadi ukuran dari bursa efek Amerika dan bursa efek Indonesia. Kedua indeks ini secara umum merupakan cerminan dari kinerja kedua bursa efek tersebut. Di Indonesia, kinerja indeks harga saham gabungan telah mengalami volatilias pergerakan yang cukup signifikan dari waktu ke waktu. Tercatat bahwa selama periode penelitian, dari bulan Januari 2007 sampai dengan Juli 2014, terdapat perubahan nilai indeks yang cukup dramatis. Hal ini ditunjukkan dengan tingginya tingkat fluktuasi dari kondisi resesi dan recovery nilai indeks. Pada tahun 2007, terlihat pada Gambar 5.1 bahwa nilai IHSG sempat terkoreksi dengan niai yang sangat besar, dari 2800 rupiah dari tahun 2007 menjadi sekitar 1300 rupiah pada tahun 2009 .

Signifikan dan drastisnya penurunan nilai indeks dipicu oleh beberapa faktor, seperti terintegrasinya pasar modal Indonesia yang diwakili oleh IHSG turut dipengaruhi dampak negatif dari melemahnya kinerja ekonomi global, sehingga memicu terjadinya krisis keuangan global yang berimplikasi pada melemahnya pasar-pasar saham di dunia. Pada awalnya, krisis yang terjadi tersebut berasal dari kegagalan pemerintah Amerika untuk melakukan pengelolaan hutang yang nilainya lebih besar bila dibandingkan dengan nilai Gross National Product (GNP). Selain itu, macetnya kredit perumahan di Amerika yang dikenal dengan Subprime mortage juga menjadi indikasi awal kesulitan keuangan yang dialami Negara super power tersebut. Dengan demikian, dampak negatif tersebut turut berimpikasi pada kinerja pasar modal global termasuk pasar-pasar di kawasan Asia, terutama Indonesia.

\section{Gambar 2. Perkembangan Pergerakan Nilai Indeks IHSG Selama Periode 1 Januari 2007 - Juli} 2014 


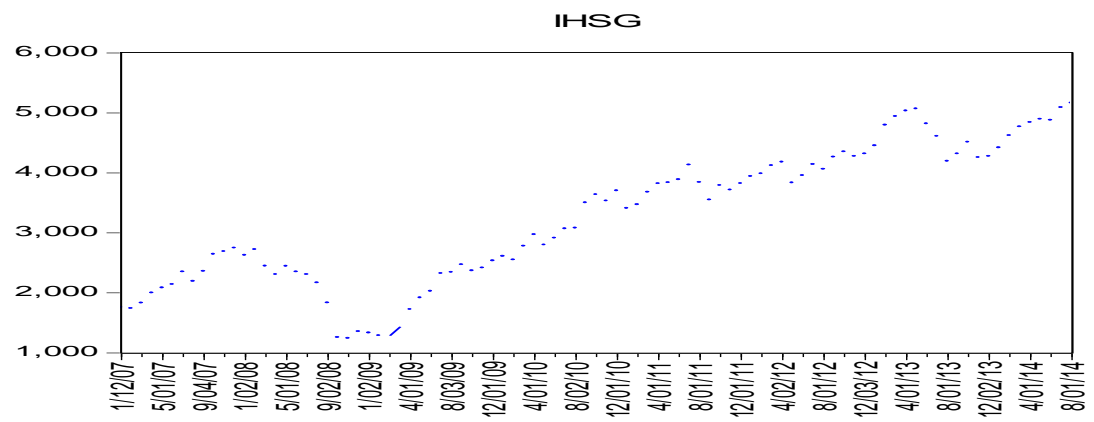

Sumber: Hasil Penelitian, 2014.

Gambar 1 menunjukkan tingginya tingkat fluktuasi indeks harga saham gabungan yang menjadi proksi dari kinerja psar modal Indonesia. Selanjutnya kami juga melakukan plotting terhadap kondisi rill dari bursa efek Amerika yang diukur dengan menggunakan nilai Dow Jones Industrial Index. Dari informasi yang tertera pada Gambar 2, dapat dilihat bahwa pergerakan DJI juga mencerminkan fluktuasi yang sangat tajam, di mana kondisi resesi yang dialami oleh Amerika sagat berdampak buruk terhadap perekonomian Negara tersebut. Pada tahun 2007, nilai DJI sempat menembus angka 14.000 Dollar yang berarti bahwa kinerja DJI menunjukkan performa yang positif selama periode operasional. Namun demikian situasi berubah pada pertengahan tahun 2009, di mana nilai DJI terkoresi negatif ke level 7.000 Dollar.

Gambar 3. Perkembangan Pergerakan Nilai Indeks DJI Selama Periode 1 Januari 2007 - Juli 2014

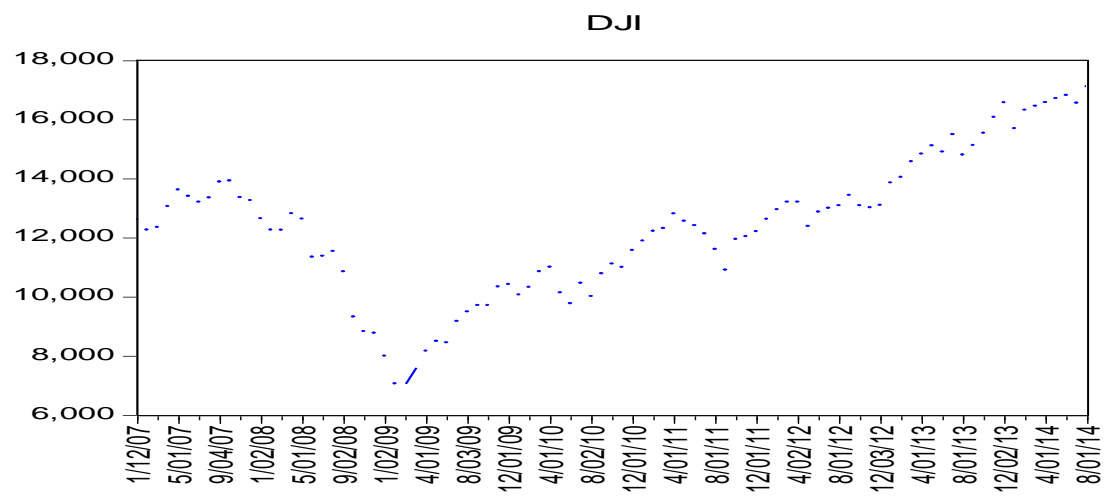

Sumber: Hasil Penelitian, 2014.

Gambar 2 di atas memperlihatkan bahwa meskipun terjadi koreksi yang cukup tajam sebagai akibat dari buruknya pengelolaan sistem keuangan di tahun 2009, DJI sebagai proksi dari ukuran kinerja bursa efek Indonesia dapat menunjukkan performa positif sehingga kembali menembus level 16.599 dollar pada tahun 2013. Hal ini terjadi karena telah muncul beberapa aktivitas Initial Public Offering (IPO) yang cukup fenomenal, seperti penjualan saham perdana raksasa teknologi Facebook yang dengan nilai 20 Dollar perlembar saham. Selain itu, pemerintah Amerika juga mendapatkan bailout keuangan sehingga dapat dengan cepat dapat melakukan revitalisasi terkait masalah penanganan dampak krisis yang dialaminya.

Semakin baiknya perkembangan perekonomian Amerika yang tercermin pada kinerja DJI juga berimplikasi positif terhadap kinerja IHSG di Bursa Efek Indonesia. Seperti terlihat pada pada Gambar 3, apabila dilakukan komparasi mengenai kinerja IHSG dan DJI selama kurun waktu pengamatan yang sama, terlihat bahwa meskipun kinerja IHSG masih berada jauh dari DJI, namun pola pergerakan yang ditunjukkan oleh kedua indeks menunjukkan adalnya hubungan jangka panjang yang dikenal dengan hubungan kointegrasi. Selain itu, juga terdapat hubungan kausalitas antara kedua indeks, di mana peningkatan nilai DJI berhubungan positif dengan peningkatan IHSG.

Gambar 4. Perkembangan Pergerakan Nilai Indeks DJI dan IHSG Selama Periode Waktu 1 Januari 2007 - Juli 2014 


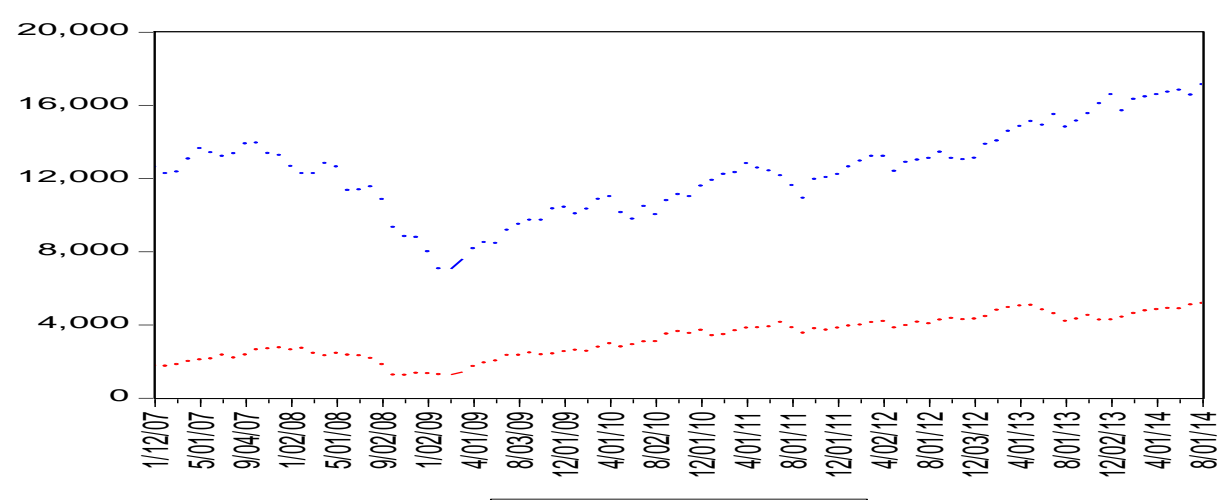

- DJI —IHSG

Sumber: Hasil Penelitian, 2014.

\section{Uji Stasioneritas (Unit Root Test)}

Berdasarkan uji akar unit dengan menggunakan Augmented Dickey fuller (ADF) dan Dickey fuller (DF), kedua variabel yang dianalisa dalam penelitian ini baru stasioner setelah didiferensiasikan pada orde pertama. Uji dilakukan pada tingkat none. Berikut hasil dari uji akar unit variabel DJI dan IHSG pada first different:

\section{Tabel 1 Uji Root Test Pada Variabel IHSG (First First Difference)}

Null Hypothesis: D(IHSG) has a unit root

Exogenous: None

Lag Length: 0 (Automatic based on SIC, MAXLAG=11)

\begin{tabular}{lrrr} 
& & t-Statistic & \multicolumn{1}{c}{ Prob.* } \\
\hline & & & \\
Augmented Dickey-Fuller test statistic & -7.793464 & 0.0000 \\
Test critical values: & 1\% level & -2.590622 & \\
& $5 \%$ level & -1.944404 & \\
$10 \%$ level & -1.614417 &
\end{tabular}

*MacKinnon (1996) one-sided p-values.

Augmented Dickey-Fuller Test Equation

Dependent Variable: D(IHSG,2)

Method: Least Squares

Date: 10/09/14 Time: 07:55

Sample (adjusted): 3/01/2007 8/01/2014

Included observations: 91 after adjustments

\begin{tabular}{lclrr}
\hline \multicolumn{1}{c}{ Variable } & Coefficient & Std. Error & t-Statistic & Prob. \\
& & & & \\
\multicolumn{1}{c}{ D(IHSG(-1)) } & -0.806813 & 0.103524 & -7.793464 & 0.0000 \\
\hline R-squared & & & \\
Adjusted R-squared & 0.402926 & Mean dependent var & 1.019121 \\
S.E. of regression & 0.402926 & S.D. dependent var & 231.0189 \\
Sum squared resid & 178.5096 & Akaike info criterion & 13.21809 \\
Log likelihood & 2867910. & Schwarz criterion & 13.24568 \\
Durbin-Watson stat & -600.4231 & Hannan-Quinn criter. & 13.22922 \\
Sumber: Hasil estimasi menggunakan E Views 6. & \\
Catatan * signifikan pada $\alpha=5 \%$ & &
\end{tabular}

Tabel 2 Uji Root Test Pada Variabel DJI (First First Difference) 
Null Hypothesis: D(DJI) has a unit root

Exogenous: None

Lag Length: 0 (Automatic based on SIC, MAXLAG=11)

\begin{tabular}{lrrr}
\hline & & t-Statistic & Prob. $^{*}$ \\
\hline & & & \\
Augmented Dickey-Fuller test statistic & -8.184819 & 0.0000 \\
Test critical values: & 1\% level & -2.590622 & \\
$5 \%$ level & -1.944404 & \\
$10 \%$ level & -1.614417 &
\end{tabular}

*MacKinnon (1996) one-sided p-values.

Augmented Dickey-Fuller Test Equation

Dependent Variable: D(DJI,2)

Method: Least Squares

Date: 10/09/14 Time: 08:15

Sample (adjusted): 3/01/2007 8/01/2014

Included observations: 91 after adjustments

\begin{tabular}{lrlrr}
\hline \multicolumn{1}{c}{ Variable } & Coefficient & \multicolumn{1}{c}{ Std. Error } & t-Statistic & Prob. \\
& & & & \\
\multicolumn{1}{c}{ D(DJI(-1) } & -0.857733 & 0.104796 & -8.184819 & 0.0000 \\
\hline R-squared & 0.426580 & Mean dependent var & 10.01945 \\
Adjusted R-squared & 0.426580 & S.D. dependent var & 645.0424 \\
S.E. of regression & 488.4552 & Akaike info criterion & 15.23130 \\
Sum squared resid & 21472963 & Schwarz criterion & 15.25889 \\
Log likelihood & -692.0242 & Hannan-Quinn criter. & 15.24243 \\
Durbin-Watson stat & 1.961566 & & \\
\hline
\end{tabular}

Sumber: Hasil Penelitian, 2014.

\section{Penentuan Lag Optimal}

Sebelum estimasi terhadap model VAR dilakukan, hal pertama yang harus dilakukan adalah menentukan berapa panjang lag yang tepat dalam model VAR. Pada dasarnya, semakin panjang lag dalam model VAR bisa menggambarkan cakupan analisis yang lebih luas dari perilaku dinamis data. Tetapi semakin panjang lag dalam model, akan semakin mengurangi degree of freedom (Kurnia 2005). Dalam penelitian ini, ditentukan panjang lag yang ditetapkan adalah sepanjang 6 lag.

Untuk menentukan lag length optimal, pada penelitian ini menggunakan kriteria informasi dengan menggunakan metode Akaike Information Criterion (AIC), Schwarz Criterion (SC) dan HannanQuinn (HQ). Dari hasil uji tersebut dapat diketahui bahwa E Views 6 telah merekomendasikan lag optimal pada model VAR tersebut. Hasil menunjukan bahwa jumlah lag optimal yang direkomendasaikan adalah lag 6. Proses pengujian dalam penentuan lag length optimal pada penelitian ini menggunakan perangkat lunak E-Views versi 6. Hasil output dapat dilihat pada Tabel Berikut:

Tabel 3 Hasil lagOptimal dengan Menggunakan Model VAR

\begin{tabular}{clccc}
\hline Model 1 & Lag & AIC & SC & HQ \\
\hline & 0 & 16.03093 & 16.08539 & 16.05292 \\
1 & 16.05569 & 16.11051 & 16.07781 \\
2 & 16.01668 & 16.09946 & 16.05008 \\
3 & 15.95576 & 16.06686 & 16.00056 \\
4 & 15.88145 & 16.02126 & 15.93780 \\
5 & 15.78864 & 15.92940 & 15.84535 \\
\hline $\mathbf{6}$ & $\mathbf{1 5 . 7 4 0 2 7}$ & $\mathbf{1 5 . 9 3 8 6 7}$ & $\mathbf{1 5 . 8 2 0 1 6}$ \\
\hline
\end{tabular}

Sumber: Hasil Penelitian, 2014.

\section{Uji Kausalitas Granger (Granger Test)}

Granger (1983) dalam Widarjono (2009) menyatakan bahwa keberadaan variabel nonstasioner menyebabkan kemungkinan besar adanya hubungan jangka panjang antara variabel di dalam sistem VAR. Hubungan kausalitas dua arah terjadi dari variabel DJI terhadap IHSG pada $\alpha=5 \%$

Tabel 4 Granger Test Result 
Date: 10/09/14 Time: 08:42

Sample: $1 / 12 / 2007$ 8/01/2014

Lags: 2

\begin{tabular}{lccr}
\hline Null Hypothesis: & Obs & F-Statistic & Prob. \\
\hline IHSG does not Granger Cause DJI & 91 & 2.17857 & 0.1194 \\
DJI does not Granger Cause IHSG & & 0.20141 & 0.8180 \\
\hline
\end{tabular}

Sumber: Hasil Penelitian, 2014.

\section{Uji Kointegrasi (Cointegration Test)}

Uji kointegrasi dilakukan untuk mengetahui kemungkinan terjadinya kestabilan jangka panjang (long run equilibrium) di antara variabel-variabel yang diamati. Uji kointegrasi dalam penelitian ini menggunakan pendekatan Johansen dan didapat hasil analisis sebagai berikut:

\section{Tabel 5 Cointegration Test Result}

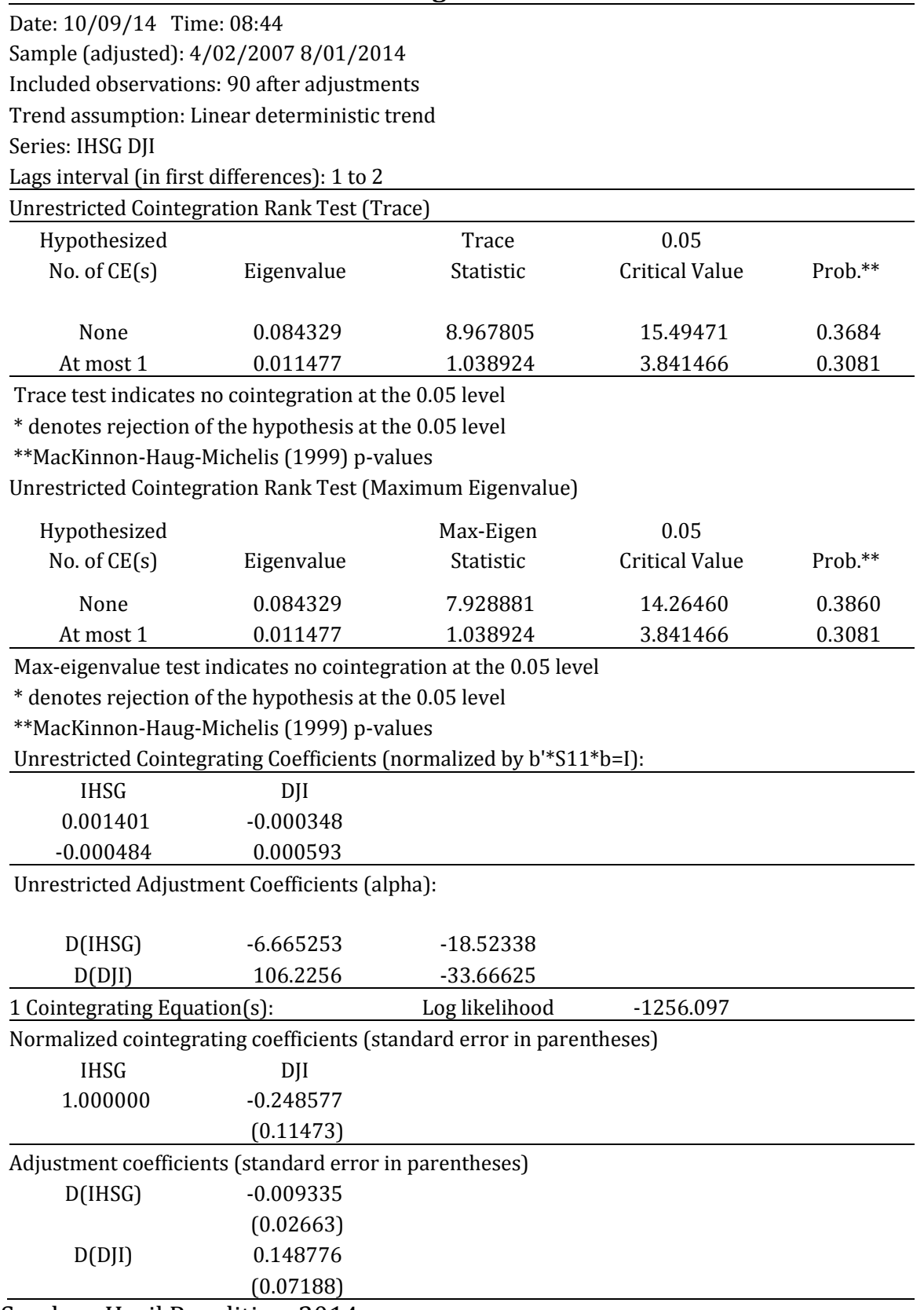

Sumber: Hasil Penelitian, 2014.

Dari hasil estimasi model Johansen maka dapat diketahui bahwa data tidak menunjukan adanya hubungan kointegrasi. Pada Tabel hasil estimasi kointegrasi dapat diketahui nilai trace statistic dan max 
eigen statistic masing-masing lebih kecil daripada critical value-nya baik pada tingkat 5\% maupun $1 \%$. Setelah diketahui bahwa tidak terdapat hubungan kointegrasi pada tiap variabel, maka dapat dipastikan bahwa model yang digunakan dalam penelitian ini adalah VAR (Vector Autoregression) bentuk differensi.

\section{Hasil Estimasi Vector Autoregression Bentuk Differensi}

Model VAR menganggap bahwa semua variabel ekonomi adalah saling tergantung dengan yang lain (Widarjono, 2009). Hal ini sangat mungkin terjadi karena masing-masing faktor yang menjadi variabel penentu kinerja dari sebuah variabel memiliki interdependensi. Setelah dilakukan pengolahan data melalui model VAR bentuk differensi dengan menggunakan E Views 6 maka hasil yang dapat diketahui mengenai output estimasi bentuk VAR pada bursa efek Amerika dan Bursa efek Indonesia adalah sebagai berikut:

Tabel 6 Output Estimasi Vector Auto Regression Bentuk Differensi

\begin{tabular}{|c|c|c|}
\hline \multicolumn{3}{|c|}{$\begin{array}{l}\text { Vector Autoregression Estimates } \\
\text { Date: } 10 / 09 / 14 \text { Time: 08:55 } \\
\text { Sample (adjusted): 7/02/2007 8/01/2014 } \\
\text { Included observations: } 87 \text { after adjustments } \\
\text { Standard errors in () \& t-statistics in [] }\end{array}$} \\
\hline & IHSG & DJI \\
\hline IHSG(-1) & $\begin{array}{c}1.213044 \\
(0.14041) \\
{[8.63924]}\end{array}$ & $\begin{array}{c}0.201168 \\
(0.37089) \\
{[0.54239]}\end{array}$ \\
\hline IHSG(-2) & $\begin{array}{r}-0.445346 \\
(0.21684) \\
{[-2.05379]} \\
\end{array}$ & $\begin{array}{r}-0.081719 \\
(0.57278) \\
{[-0.14267]} \\
\end{array}$ \\
\hline IHSG(-3) & $\begin{array}{c}0.482477 \\
(0.22013) \\
{[2.19178]} \\
\end{array}$ & $\begin{array}{r}0.501300 \\
(0.58147) \\
{[0.86213]} \\
\end{array}$ \\
\hline IHSG(-4) & $\begin{array}{r}-0.502414 \\
(0.22116) \\
{[-2.27168]} \\
\end{array}$ & $\begin{array}{r}-0.920176 \\
(0.58420) \\
{[-1.57511]}\end{array}$ \\
\hline IHSG(-5) & $\begin{array}{r}0.275406 \\
(0.21876) \\
{[1.25893]}\end{array}$ & $\begin{array}{r}0.880828 \\
(0.57785) \\
{[1.52432]} \\
\end{array}$ \\
\hline IHSG(-6) & $\begin{array}{r}-0.021710 \\
(0.13956) \\
{[-0.15557]}\end{array}$ & $\begin{array}{r}-0.372509 \\
(0.36863) \\
{[-1.01052]}\end{array}$ \\
\hline DJI(-1) & $\begin{array}{r}-0.008533 \\
(0.05344) \\
{[-0.15967]}\end{array}$ & $\begin{array}{r}0.998492 \\
(0.14116) \\
{[7.07324]}\end{array}$ \\
\hline DJI(-2) & $\begin{array}{c}0.075710 \\
(0.07598) \\
{[0.99646]}\end{array}$ & $\begin{array}{r}-0.142498 \\
(0.20069) \\
{[-0.71003]}\end{array}$ \\
\hline DJI(-3) & $\begin{array}{r}-0.083043 \\
(0.07756) \\
{[-1.07074]}\end{array}$ & $\begin{array}{c}0.038072 \\
(0.20486) \\
{[0.18584]}\end{array}$ \\
\hline DJI(-4) & $\begin{array}{c}0.036979 \\
(0.07792) \\
{[0.47456]}\end{array}$ & $\begin{array}{r}0.288344 \\
(0.20583) \\
{[1.40087]}\end{array}$ \\
\hline DJI(-5) & $\begin{array}{r}-0.006459 \\
(0.07591) \\
{[-0.08508]} \\
\end{array}$ & $\begin{array}{r}-0.306753 \\
(0.20053) \\
{[-1.52974]}\end{array}$ \\
\hline DJI(-6) & $\begin{array}{r}-0.027282 \\
(0.05189) \\
{[-0.52574]} \\
\end{array}$ & $\begin{array}{r}0.036519 \\
(0.13707) \\
{[0.26642]}\end{array}$ \\
\hline $\mathrm{C}$ & $\begin{array}{r}178.5348 \\
(122.920) \\
{[1.45244]}\end{array}$ & $\begin{array}{r}411.3620 \\
(324.689) \\
{[1.26694]}\end{array}$ \\
\hline $\begin{array}{l}\text { R-squared } \\
\text { Adj. R-squared }\end{array}$ & $\begin{array}{l}0.976858 \\
0.973105\end{array}$ & $\begin{array}{l}0.967302 \\
0.962000\end{array}$ \\
\hline
\end{tabular}




\begin{tabular}{lrr} 
Sum sq. resids & 2436719. & 17001804 \\
S.E. equation & 181.4625 & 479.3267 \\
F-statistic & 260.3010 & 182.4288 \\
Log likelihood & -568.8987 & -653.4048 \\
Akaike AIC & 13.37698 & 15.31965 \\
Schwarz SC & 13.74545 & 15.68812 \\
Mean dependent & 3344.305 & 12310.83 \\
S.D. dependent & 1106.498 & 2458.888 \\
\hline Determinant resid covariance (dof adj.) & $5.15 \mathrm{E}+09$ \\
Determinant resid covariance & $3.73 \mathrm{E}+09$ \\
Log likelihood & -1205.599 \\
Akaike information criterion & 28.31262 \\
Schwarz criterion & 29.04956 \\
\hline Sumber: Hasil Penelitian 2014. &
\end{tabular}

Sumber: Hasil Penelitian, 2014.

\section{Hasil Impulse Response}

Estimasi terhadap fungsi impulse response bertujuan untuk menelusuri dampak goncangan (shock) variabel inovasi terhadap variabel lainnya. Berdasarkan hasil estimasi, dampak respon yang diterima akibat goncangan variabel dapat dilihat secara grafis. Dari Gambar 5.4 di bawah dapat diketahui bahwa dampak respon suatu variabel akibat shock variabel lainnya sampai dengan sepuluh periode setelah (shock) semakin melebar.

\section{Gambar 4 Impulse Response Sampai 10 Kuartal}

Response to Cholesky One S.D. Innovations \pm 2 S.E.
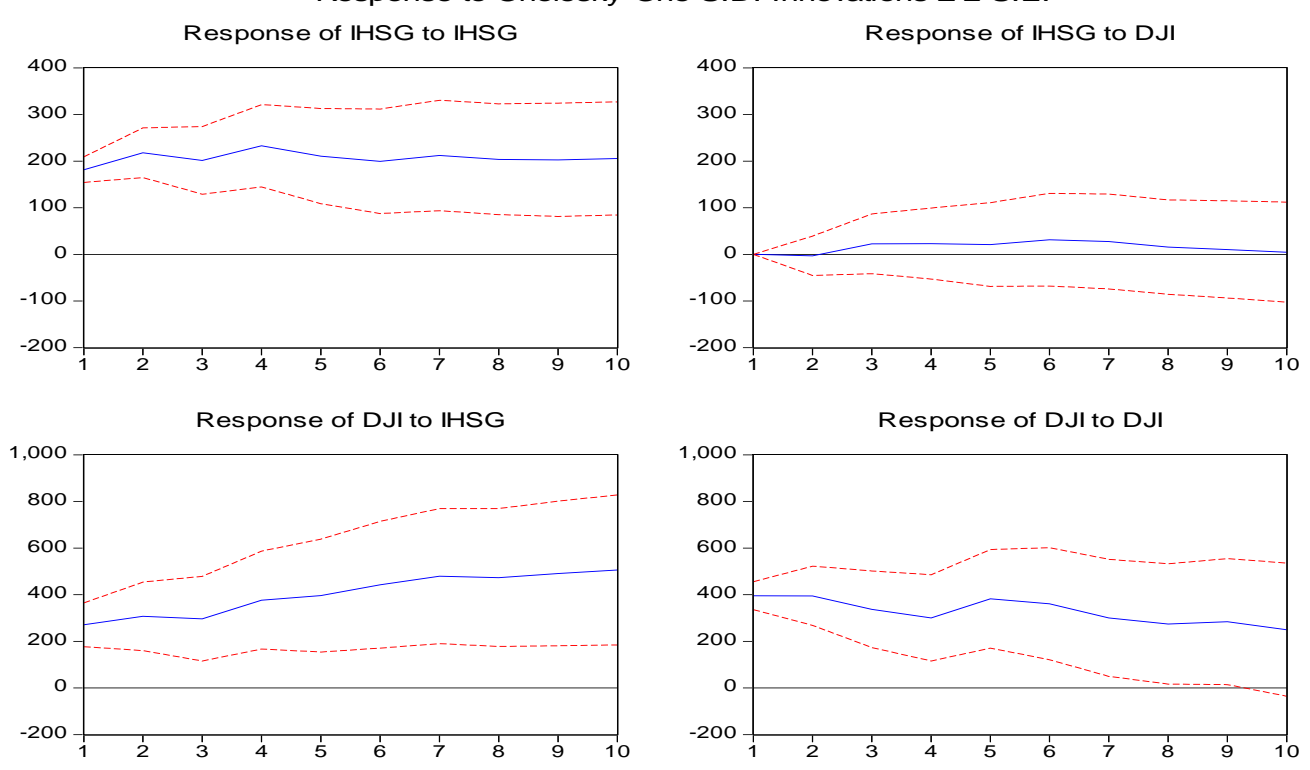

Sumber: Hasil estimasi Impulse Response model VAR dengan bentuk Differensi (Hasil estimasi menggunakan E Views 6).

Gambar 4 di atas menggambarkan fungsi impulse response dengan pengamatan sepuluh (10) kuartal setelah shock. Dari Gambar tersebut tampak dari pengamatan sampai dengan sepuluh kuartal setelah shock, dampak respon yang diterima oleh IHSG akibat goncangan semakin besar. Hal ini terlihat dari paramater variabel IHSG dan DJI yang semakin melebar.

\section{Variance Decomposition}

Variance decomposition bertujuan untuk memisahkan dampak masing-masing variabel inovasi tersebut secara individual terhadap respon yang diterima suatu variabel (Kurnia, 2005). Hasil variance decomposition pada persamaan VAR bentuk differensi difokuskan pada kontribusi shock variabel DJI terhadap Variabel IHSG. Hal ini dapat dilihat pada Tabel berikut:

\section{Tabel 7 Variance Decomposition}


Decomposition of IHSG:

Period S.

\begin{tabular}{|c|c|c|c|}
\hline Period & & IHSG & \\
\hline 1 & 181.4625 & 100.0000 & 0.000000 \\
\hline 2 & 283.5177 & 99.98582 & 0.014176 \\
\hline 3 & 348.4255 & 99.57418 & 0.425824 \\
\hline 4 & 419.7388 & 99.40753 & 0.592465 \\
\hline 5 & 470.0858 & 99.32797 & 0.672026 \\
\hline 6 & 511.6237 & 99.05782 & 0.942178 \\
\hline 7 & 554.5093 & 98.95156 & 1.048442 \\
\hline 8 & 590.9818 & 99.00832 & 0.991681 \\
\hline 9 & 624.8538 & 99.08556 & 0.914442 \\
\hline 10 & 657.7828 & 99.17007 & 0.829928 \\
\hline Mean & & 99.36 & 0.64 \\
\hline \multicolumn{4}{|c|}{$\begin{array}{c}\text { Variance } \\
\text { Decomposition of } \\
\text { DJI: }\end{array}$} \\
\hline Period & S.E. & IHSG & DJI \\
\hline 1 & 479.3267 & 31.88767 & 68.11233 \\
\hline 2 & 692.7335 & 34.87744 & 65.12256 \\
\hline 3 & 825.6677 & 37.46575 & 62.53425 \\
\hline 4 & 955.9005 & 43.46778 & 56.53222 \\
\hline 5 & 1102.979 & 45.53954 & 54.46046 \\
\hline 6 & 1241.868 & 48.59852 & 51.40148 \\
\hline 7 & 1364.644 & 52.59087 & 47.40913 \\
\hline 8 & 1470.141 & 55.67892 & 44.32108 \\
\hline 9 & 1575.657 & 58.16988 & 41.83012 \\
\hline 10 & 1673.635 & 60.70346 & 39.29654 \\
\hline Mean & & 46,90 & 53.10 \\
\hline
\end{tabular}

Cholesky Ordering: IHSG DJI

Sumber: Hasil Penelitian, 2014.

Berdasarkan informasi pada Tabel di atas yang didapat melalui dekomposisi varian fungsi impulse response tampak bahwa respon respon IHSG lebih banyak disebabkan karena goncangan pada DJI dengan proporsi $99.36 \%$. Proporsi nilai rata-rata DJI adalah $0.64 \%$. Sedangkan respon IHSG disebabkan oleh shock DJI dengan proporsi 53.10 \%. Sisanya sebesar 46.90 \% disebabkan karena shock IHSG.

\section{Diskusi}

Hubungan antara dua pasar modal dari dua negara atau lebihh merupakan sebuah fenomena yang menarik untuk dikaji secara lebih mendalam. Hingga saat ini, globalisasi yang tidak terbendung mengindikasikan bahwa kesempatan untuk mendapatkan peluang serta nilai ekonomis atas sebuah kejadian atau kerjasama yang disetujui dalam sebuah kesepakatan dapat memberikan dampak positif dari sisi keuntungan. Namun, sesuai dengan konsep high risk high return, ada trade off atas setiap keputusan yang diambil. Salah satu keputusan untuk membuat ekonomi terbuka juga menjadi sebuah keputusan yang dilemma. Disatu sisi, akan ada hubungan timbal balik yang bersifat positif maupun negatif. Dengan demikian, langkah pengambilan keputusan dalam membina hubungan jangka panjang akan berdampak pada kinerja pasar modal dan kinerja ekonomi dari kedua negara yang saling bekerja sama dan berintegrasi satu sama ain.

Beberapa penelitian terdahulu menduga bahwa ada hubungan jangka panjang (kointegrasi) antara dua atau lebih bursa saham yang menjadi fokus utama dalam kajian ini. Dalam konteks ini, peneliti menduga bahwa bursa saham Amerika dan juga Bursa saham Indonesia memiliki hubungan yang cukup dinamis. Hal ini ini cukup beralasan karena Indonesia dan Amerika telah membangun hubungan kerjasama baik dalam bidang perdagangan, politik, sosial budaya dan juga ekonomi dalam jangka waktu yang panjang.

Hasil yang diperoleh dari penelitian ini mengungkapkan bahwa terdapat hubungan jangka panjang antara Bursa Efek Amerika yang diwakili oleh Dow Jones Industrial Index (DJI) dengan Bursa Efek Indonesia yang diwakili oleh Indeks Harga Saham Gabungan (IHSG). Hal ini dapat dibuktikan dari hasil 
pengujian hubungan (Cointegration test) melalui Estimasi VAR dalam bentuk differensi. Pada awalnya, perilaku data dari kedua variabel ini cukup ekstrim, karena menunjukkan perilaku data yang tidak stasioner. Hal ini disebabkan perilaku data pada DJI cenderung berbeda jauh dengan perilaku data IHSG. Namun demikian, berbedanya perilaku data dari kedua variabel tersebut dipengaruhi oleh faktor kelambanan (lag), di mana lag memainkan peran besar sehingga setelah dilakukan uji kointegrasi, data menjadi stasioner pada lag 6. Hal ini mengindikasikan bahwa kinerja pasar modal dipengaruhi oleh kinerja atau prestasi sebelumnya dari pasar modal itu sendiri dan juga faktor lainnya.

Adanya hubungan yang signifikan antara bursa efek Amerika dan bursa efek Indonesia juga didukung aktivitas perdagangan luar negeri yang terjadi pada kedua negara tersebut. Indonesia, adalah salah satu pasar supplier terbesar yang memasok berbagai bahan baku untuk pasar industri Amerika. Sedangkan Amerika, turut menjadi pasar supplier terbesar sebagai pemasok berbagai macam produk manufaktur maupun non manufaktur ke Indonesia. Secara teori, kinerja pasar modal dari dua Negara ini seharusnya saling berkaitan erat. Namun demikian, perilaku kedua data tidak menunjukkan demikian. Amerika merasakan dampak negatif yang lebih hebat sebagai akibat dari adanya krisis keuangan yang terjadi di Yunani dan menular ke Eropa hingga Asia. Amerika sebagai salah satu pemain besar merasakan dampak negatif seperti turunnya kegiatan ekspor barang ke dari Amerika dan ke pasar Eropa.

Fenomena krisis global yang turut melanda Asia (China, Jepang, Korea, India, Malaysia, Singapura) tidak terlalu berimbas negatif terhadap kinerja pasar modal Indonesia. Hal ini dikarenakan tidak terlalu besarnya ketergantungan Indonesia terhadap Amerika dan Eropa. Namun, Indonesia juga merasakan dampak negatif karena kinerja pasar modal Amerika juga menurun selama kurun waktu tahun 2009. Sebagai langkah untuk mengantisipasi hal tersebut, Indonesia lebih memperkuat perekonomian nasional dengan mengutamakan sektor rill dan sektor industri kreatif, sehingga meskipun kondisi keuangan global sedang berada dalam situasi yang rumit (resession), Indonesia masih bisa mencatatkan kinerja pertumbuhan ekonomi yang kuat, yaitu di atas $6 \%$ pertahun. Hal yang yang sama juga mulai terjadi di Amerika, meskipun pertumbuhan ekonominya cenderung menurun pasca terjadinya shock krisis global, namun Amerika sudah mulai menunjukkan kinerja yang kembali positif. Dengan demikian, terdapat hubungan jangka panjang antara kedua bursa saham ini, karena aktivitas perekonomiannya saling terafiliasi. Beberapa hal yang membedakan adalah, Amerika merupakan salah satu pemain global yang menjadi pusat perhatian Dunia, sedangkan Indonesia merupakan salah satu Negara berkembang yang baru akan meningkatkan kinerja ekonominya, di mana hal tersebut terbukti ketika Indonesia masuk dalam kategori Negara dengan pertumbuhan ekonomi terbesar di dunia selama beberapa waktu terakhir ini.

Secara tidak langsung, hasil yang diungkapkan melalui penelitian ini menunjukkan bahwa semakin terintegrasinya pasar modal suatu negara dengan pasar modal di negara lainnya akan turut berdampak pada kinerja jangka panjang. Industri keuangan yang semakin canggih dan semakin terintegrasi juga mengindikasikan adanya kemungkinan bahwa pasar modal tersebut akan rentan terhadap dampak sistemik atau contagion effect yang muncul seagai akibat dari negatif atau memburuknya pasar modal yang menjadi rekan atau terintegrasi dengan kuat dengan pasar modal tersebut. Dengan demikian, reaksi pasar yang berlebihan tidak dapat dielakkan dan dapat berkontribusi negatif terhadap kinerja keseluruhan dari pasar modal yang terintegrasi. Namun demikian, apabila counterpart atau pasar modal partner yang saling terintegrasi tersebut mengalami pertumbuhan kinerja yang positif, juga akan turut memberikan kontribusi yang positif terhadap peningkatan nilai dari kedua bursa tersebut.

\section{KESIMPULAN}

Setelah dilakukan analisis terhadap pergerakan nilai Bursa Efek Amerika yang diproksi oleh Dow Jones Industrial Index (DJI) dan Bursa Efek Indonesia yang diproksi oleh Indeks Harga Saham Gabungan (IHSG), maka hasil estimasi dengan menggunakan model Vector Autoregressive yang diinterpreastikan dengan fungsi impulse response dan variance decomposition menghasilkan beberapa simpulan sebagai berikut:

1. Krisis keuangan yang terjadi di Amerika yang diproksi oleh Dow Jones Industrial Index (DJI) berpengaruh positif terhadap pergerakan Bursa Efek Indonesia yang diproksi oleh Indeks Harga Saham Gabungan (IHSG). Hal ini dapat dilihat dari hubungan jangka panjang yang muncul dari kedua variabel, di mana dalam jangka waktu yang panjang, bursa efek indonesia (IHSG) cenderung bergerak searah dengan performa yang ditunjukkan oleh bursa efek Amerika (DJI)

2. Respon Dow Jones Industrial Index (DJI) lebih banyak disebabkan oleh goncangan pada DJI itu sendiri, sedangkan respon Indeks Harga Saham Gabungan (IHSG) disebabkan oleh shock Dow Jones Industrial Index (DJI). Hal ini dapat dilihat dari perbedaan kinerja dan rata-rata (mean) fungsi impulse response yang muncul, di mana pasar modal Amerika sangat terintegrasi dengan pasar 
modal maju di negara lainnya. Sedangkan Indonesia terintegrasi dengan pasar modal Amerika, namun kurang terintegrasi dengan pasar modal maju lain di lokasi yang berbeda.

\section{DAFTAR PUSTAKA}

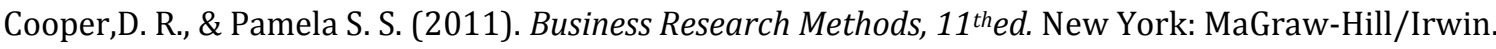

Gujarati, N. D. (1995). Basic Econometrics, Third Edition. New York: MacGraw—Hill.

Harris, R. (1995). Cointegration Analysis in Econometric Modelling. New York: Prentice Hall.

Husnan, S. (1994). Invetsasi Di Pasar Modal, Perkembangan, Kecenderungan, Kebutuhan dan Prospek. Kelola. No 7. III. Pp 100-113.

Insukindro.(1998). Syndrum $\mathrm{R}^{2}$ Dalam Analisis Regresi Linear Runtun Waktu. Jurnal Ekonomi dan Bisnis Indonesia. Vol.13. No.4 pp 1-11.

Kaniawati.(2009). Analisis Perbandingan DJIA Performance Sebelum dan Sesudah Bailout 3 Oktober 2008 dan Pengaruhnya Terhadap Bursa di Berbagai Negara. Jurnal Bisnis dan Manajemen. Vol X. No. 1 pp. 49-71.

Kurnia, S. A. (2005). Ananlisis Interdependensi Neraca Transaksi Berjalan Neraca Modal Indonesia Pendekatan Model Vector Autoregressive dan Vector Error Correction 1981.1-2002.3. Jurnal Ekonomi Pembangunan. Pp 43-66.

Mauliano, A. D. (2009). Analisis Faktor-Faktor yang mempengaruhi Pergerakan Indeks Harga Saham Gabungan (IHSG) di Bursa Efek Indonesia. (Tesis Tidak Dipublikasikan) Universitas Gunadharma.

Media Indonesia.(2011). http://www.mediaindonesia.com/read/2011/12/30/288122/20/2/IHSG Terbaik-Kedua-Se-Asia-Pasific (Diakses Tanggal 5 Januari 2012 pukul 16.45 WIB).

Nurazi, R., Zulkarnain, I., \& Kananlua, P S. (2013). Analisis Kointegrasi dan Hubungan Dinamis antara Bursa Efek Cina dan Bursa Efek Indonesia. Laporan Penelitian Dosen Jurusan Manajemen.

Widarjono, A. (2009). Ekonometrika Pengantar dan Aplikasinya. Yogyakarta: Ekonisia Fakultas Eknomi UII.

BAPEPAM, (2008). Analisis hubungan kointegrasi dan Kausalitas serta hubungan dinamis antara Aliran modal asing, perubahan nilai tukar Dan pergerakan ihsg di pasar modal Indonesia. Badan pengawas pasar modal dan lembaga keuangan Departemen keuangan republik Indonesia.

Lestari, M. (2005) Pengaruh Variabel Makro Terhadap Return Saham Di Bursa Efek Jakarta: Pendekatan Beberapa Model. Simposium Akuntansi Nasional VIII. Solo. Pp 504-513.

Parthapratim, P. (2006): Foreign portfolio investment Stock market and economic development: A case study of India: "Draft paper submitted for the Annual conference of Development and Change mission promoting development in a globalized world". 